\title{
Microbacterium kribbense sp. nov., isolated from soil
}

\author{
Correspondence \\ Chang-Jin Kim \\ changjin@kribb.re.kr
}

\author{
Syed G. Dastager, Jae-Chan Lee, Yoon-Jung Ju, Dong-Jin Park \\ and Chang-Jin Kim
}

\author{
Functional Metabolomics Research Center, Korea Research Institute of Bioscience and \\ Biotechnology (KRIBB), Daejeon 305-806, Republic of Korea
}

The genus Microbacterium, the type genus of the family Microbacteriaceae, was proposed by Orla-Jensen (1919) for Gram-positive, non-spore-forming, rod-shaped bacteria isolated during studies on lactic acid-producing bacteria. More recently, the description of the genus Microbacterium was emended to unite the genera Microbacterium and Aureobacterium (Takeuchi \& Hatano, 1998). Members of the genus are widespread and have been isolated from a broad range of environmental habitats, e.g. plants, soil, water, air, steep liquor, milk products and humans. At the time of writing, the genus Microbacterium comprises more than 50 recognized species. Here, we describe the phenotypic and genotypic properties of a novel Microbacterium species.

Strain MSL-04 ${ }^{\mathrm{T}}$ was isolated from a soil sample from Bigeum Island, Republic of Korea, using R2A agar medium (Difco). Routine cultivation was performed using R2A broth at $28{ }^{\circ} \mathrm{C}$. Bacterial growth was monitored for up to 7 days after inoculation by measuring the turbidity at $600 \mathrm{~nm}$. Cell morphology was observed by using light microscopy after $24 \mathrm{~h}$ cell growth. Sporulation was

The GenBank/EMBL/DDBJ accession number for the 16S rRNA gene sequence of strain MSL-O4 ${ }^{\top}$ is EF466125. observed by means of phase-contrast microscopy after the cells had reached stationary phase. Gram staining was carried out on exponentially growing cells, using Hucker's modified method (Cowan \& Steel, 1965). The presence of flagella was examined using Leifson's method (Cowan \& Steel, 1965). Growth at different temperatures, salt concentrations $(\mathrm{w} / \mathrm{v})$ and $\mathrm{pH}$ values was investigated as described by Tang et al. (2003). The $\mathrm{pH}$ was adjusted by using autoclaved $\mathrm{Na}_{2} \mathrm{CO}_{3}$. The following buffers were used to control the $\mathrm{pH}$ in $\mathrm{R} 2 \mathrm{~A}$ medium: $0.1 \mathrm{M} \mathrm{KH}_{2} \mathrm{PO}_{4} / 0.1 \mathrm{M}$ $\mathrm{NaOH}$ (pH 6.0, 7.0 and 8.0); $0.1 \mathrm{M} \mathrm{NaHCO} / 0.1 \mathrm{M}$ $\mathrm{Na}_{2} \mathrm{CO}_{3}$ (pH 9.0 and 10.0); $0.05 \mathrm{M} \quad \mathrm{Na}_{2} \mathrm{HPO}_{4} / 0.1 \mathrm{M}$ $\mathrm{NaOH}$ (pH 11.0); and $0.2 \mathrm{M} \quad \mathrm{KCl} / 0.2 \mathrm{M} \quad \mathrm{NaOH}$ $(\mathrm{pH}$ 12.0). The temperature range for growth of the organism was examined at $10-50{ }^{\circ} \mathrm{C}$ (in increments of $\left.5{ }^{\circ} \mathrm{C}\right)$. Salt tolerance was tested from 0 to $7 \% \mathrm{NaCl}(\mathrm{w} / \mathrm{v})$. Anaerobic growth was tested using incubation at $28{ }^{\circ} \mathrm{C}$ in $10 \mathrm{ml}$ rubber-stoppered, screw-capped tubes containing R2A medium $(9 \mathrm{ml}$ ) covered with liquid paraffin.

Biochemical and physiological tests were performed using the methods described by Shirling \& Gottlieb (1966). Oxidase activity was investigated by testing for oxidation of $1 \%$ benzidine (Deibel \& Ewans, 1960) and tetramethyl-pphenylenediamine (Tarrand \& Groschel, 1982). Catalase 
activity was determined by checking bubble formation in a $3 \%(\mathrm{v} / \mathrm{v})$ hydrogen peroxide solution. Acid production from carbohydrates was determined as described by Leifson (1963). Substrate utilization and enzyme activities in strain MSL- $04^{\mathrm{T}}$ were determined using API ZYM test kits (bioMérieux) according to the manufacturer's instructions.

Biomass for biochemical and chemotaxonomic characterization was prepared by culturing strain $\mathrm{MSL}-04^{\mathrm{T}}$ in trypticase soy broth at $28{ }^{\circ} \mathrm{C}$ for 5 days and then harvesting cells by centrifugation. The peptidoglycan structure was determined by the Identification Service of the Deutsche Sammlung von Mikroorganismen und Zellkulturen (Braunschweig, Germany). Qualitative analyses of amino acids and peptides in peptidoglycan hydrolysates were carried out as described by Schleifer (1985) and Schleifer \& Kandler (1972) with the modification that TLC on cellulose plates was used instead of paper chromatography. Quantitative analysis of amino acids in the total cell hydrolysate was performed using GC and GC-MS as described by MacKenzie (1987) and Groth et al. (1996).
The methods used for sugar analysis of whole-cell hydrolysates, determination of the menaquinone pattern and analysis of fatty acids were those of Li et al. (2004a, b) and Chen et al. (2004). Polar lipid profiles were determined by means of two-dimensional TLC (Minnikin et al., 1977). The genomic DNA of the bacterium was extracted and purified by using the method of Marmur (1961). The DNA G + C content of strain MSL$04^{\mathrm{T}}$ was measured using the thermal denaturation method of Marmur \& Doty (1962).

The 16S rRNA gene sequence of the isolate was amplified by using a PCR as described by Cui et al. (2001). A phylogenetic analysis was performed using the software packages PHYLIP (Felsenstein, 1993) and MEGA, version 2.1 (Kumar et al., 2001), following multiple alignment of data using CLUSTAL_X (Thompson et al., 1997). Evolutionary distances (with distance options according to Kimura's two-parameter model; Kimura, 1980, 1983) and clustering were calculated with the neighbour-joining (Saitou \& Nei, 1987) (Fig. 1) and maximum-likelihood (Felsenstein, 1981) methods. Bootstrap analysis (based on 1000 resamplings)

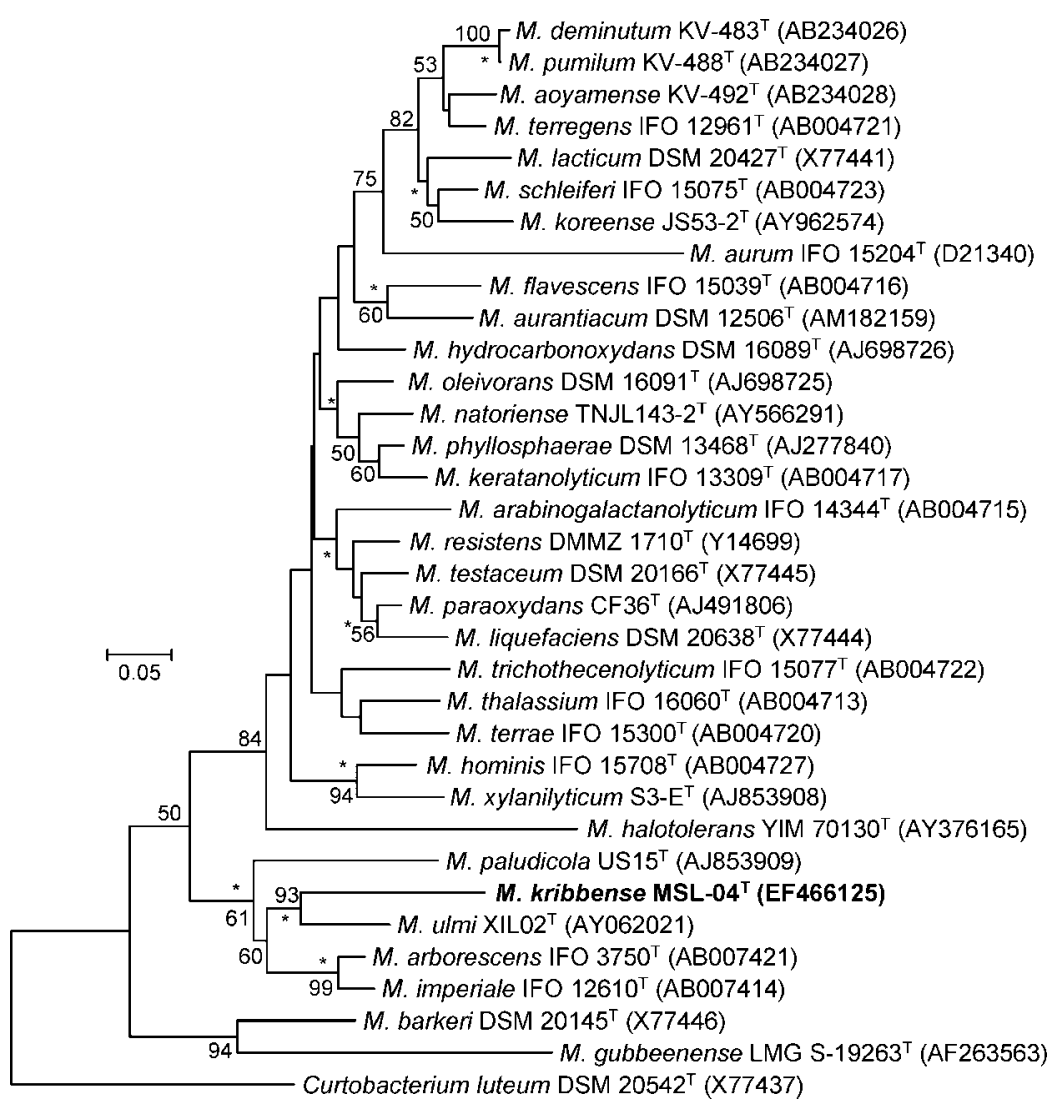

Fig. 1. Neighbour-joining phylogenetic tree, based on $16 \mathrm{~S}$ rRNA gene sequences, showing the position of strain MSL-04 ${ }^{\top}$ among species of the genus Microbacterium. Asterisks indicate branches that were also recovered using the least-squares (Fitch \& Margoliash, 1967), maximum-likelihood (Felsenstein, 1981) and maximum-parsimony (Kluge \& Farris, 1969) algorithms. Numbers at branching points refer to bootstrap values (based on 1000 resamplings). Curtobacterium luteum DSM $20542^{\top}$ was used as an outgroup. Bar, 0.05 substitutions per nucleotide position. 
was used to evaluate the tree topology of the neighbourjoining data (Felsenstein, 1985).

Strain MSL- $04^{\mathrm{T}}$ was found to comprise Gram-positive, aerobic, non-motile, non-spore-forming, short rods. Colonies were lemon-yellowish, circular, convex with entire margins, shiny, moist and approximately 0.4$0.6 \times 0.5-0.8 \mathrm{~mm}$ in size after $48 \mathrm{~h}$ growth at $28{ }^{\circ} \mathrm{C}$ in R2A medium. Growth occurred over a wide range of $\mathrm{pH}$ (7.0-11.0). The physiological and biochemical characteristics, metabolic properties and substrate-utilization results obtained for strain MSL- $04^{\mathrm{T}}$ are presented in Table 1 and in the species description below.

Strain MSL- $04^{\mathrm{T}}$ contained ornithine, alanine, glycine, homoserine and hydroxyglutamic acid in the total hydrolysate of the peptidoglycan. From these data, we concluded that the peptidoglycan type was B2 $\beta$ (Schleifer \& Kandler, 1972). Its cell-wall hydrolysate contained ribose, galactose, glucose and trace amounts of xylose. The predominant menaquinones were $\mathrm{MK}-11$ and $\mathrm{MK}-12$. The main polar lipids were diphosphatidylglycerol and phosphatidylglycerol. The major cellular fatty acids of strain MSL- $04^{\mathrm{T}}$ are $\mathrm{C}_{18: 1} \omega 7 c \quad(35.7 \%)$, anteiso- $\mathrm{C}_{15: 0} \quad(23.5 \%)$, iso- $\mathrm{C}_{16: 0}$ $(23.1 \%)$, anteiso- $\mathrm{C}_{17: 0}(9.7 \%)$, iso- $\mathrm{C}_{15: 0}(3.3 \%)$ and iso- $\mathrm{C}_{17: 0}(2.3 \%)$. To ascertain the phylogenetic position of strain MSL- $04^{\mathrm{T}}$, the almost-complete $16 \mathrm{~S}$ rRNA gene sequence (1428 nt) was determined. A phylogenetic tree demonstrated that the isolate is a member of the genus Microbacterium, and that it forms an independent phyletic line within a monophyletic subclade. The 16S rRNA gene sequence similarity between the isolate and Microbacterium type strains ranged from 93.7 to $97.5 \%$. Microbacterium ulmi LMG $20991^{\mathrm{T}}$ showed the highest sequence similarity $(97.5 \%)$ with respect to strain MSL-04 ${ }^{\mathrm{T}}$. DNA-DNA hybridization was carried out using the optical renaturation method (De Ley et al., 1970; Huß et al., 1983; Jahnke,

Table 1. Physiological and biochemical characteristics that serve to differentiate strain MSL-04 ${ }^{\top}$ from its closest phylogenetic neighbours

Strains: 1, strain MSL-04 ${ }^{\mathrm{T}}$; 2, M. ulmi LMG $20991^{\mathrm{T}}$ (data from Rivas et al., 2004); 3, M. arborescens NBRC $3750^{\mathrm{T}}$ (Imai et al., 1984); 4, M. imperiale NBRC $12610^{\mathrm{T}}$ (Collins et al., 1983). +, Positive; -, negative; v, variable reaction; w, weak reaction; ND, no data available. For the data on chemotaxonomy, components are listed in order of decreasing abundance.

\begin{tabular}{|c|c|c|c|c|}
\hline Characteristic & 1 & 2 & 3 & 4 \\
\hline Colony colour & Lemon yellow & White & Dirty orange & Red-orange \\
\hline Motility & - & - & + & + \\
\hline Catalase & - & $\mathrm{w}$ & + & + \\
\hline Hydrogen sulfide & + & - & + & $\mathrm{V}$ \\
\hline Urease & - & - & + & - \\
\hline \multicolumn{5}{|l|}{ Growth on sole carbon sources } \\
\hline$N$-Acetylglucosamine & - & - & + & $\mathrm{W}$ \\
\hline L-Arabinose & + & - & + & + \\
\hline Citrate & - & - & $\mathrm{W}$ & - \\
\hline Malate & + & - & + & + \\
\hline Mannose & + & + & - & - \\
\hline Phenyl acetate & + & + & - & - \\
\hline Propionate & - & + & - & - \\
\hline \multicolumn{5}{|l|}{ Hydrolysis of: } \\
\hline Gelatin & - & - & + & - \\
\hline Starch & + & - & - & + \\
\hline \multicolumn{5}{|l|}{ Acid production from: } \\
\hline Glycerol & + & - & + & - \\
\hline Glycogen & + & - & - & - \\
\hline Melezitose & + & - & + & - \\
\hline \multicolumn{5}{|l|}{ Chemotaxonomy } \\
\hline Menaquinones & 11,12 & $12,13,11,14,10$ & 11,12 & 11,12 \\
\hline Cell-wall diamino acid & Lys & Orn & Lys & Lys \\
\hline Cell-wall sugars ${ }^{\star}$ & Rib, Gal, Glc, Xyl & Gal, Fuc, Xyl, Rha & 6dTal, Man, Gal & Rha, Man, Gal \\
\hline Polar lipids $\dagger$ & PG, DPG & PG, DPG, L & $\mathrm{ND}$ & DPG, PG, DMG \\
\hline DNA G $+\mathrm{C}$ content $(\mathrm{mol} \%)$ & 71.0 & 69.0 & 71.0 & $71.0-75.4 \ddagger$ \\
\hline
\end{tabular}

*6dTal, 6-Deoxytalose; Fuc, fucose; Gal, galactose; Glc, glucose; Man, mannose; Rha, rhamnose; Rib, ribose; Xyl, xylose. $\nmid$ DMG, Dimannosyldiacylglycerol; DPG, diphosphatidylglycerol; PG, phosphatidylglycerol; L, unknown polar lipid. $\ddagger$ Range of values for a number of strains (Collins et al., 1983). 
1992), under optimal hybridization conditions, between strain MSL-04 ${ }^{\mathrm{T}}$, M. ulmi LMG $20991^{\mathrm{T}}$ and Microbacterium arborescens NBRC $3750^{\mathrm{T}}$. The DNA-DNA relatedness between strain MSL-04 ${ }^{\mathrm{T}}$ and M. ulmi LMG $20991^{\mathrm{T}}$ and M. arborescens NBRC $3750^{\mathrm{T}}$ was 45 and $51.2 \%$, respectively. These values are significantly lower than the $70 \%$ threshold recommended for the delineation of genomic species (Wayne et al., 1987). Therefore, the phylogenetic and DNA-DNA hybridization results from this work demonstrate that the isolate is phylogenetically closely related to members of the genus Microbacterium and is not related to any previously described Microbacterium species.

Strain MSL- $04^{\mathrm{T}}$ shares some chemotaxonomic features with members of the genus Microbacterium, i.e. the major menaquinones are MK-11 and MK-12, iso- and anteisobranched cellular fatty acids predominate and the DNA $\mathrm{G}+\mathrm{C}$ content is $71.0 \mathrm{~mol} \%$. However, it shows considerable phenotypic and genomic differences from other recognized species of the genus Microbacterium.

On the basis of the results obtained using this polyphasic approach, strain MSL- $04^{\mathrm{T}}$ represents a novel species of the genus Microbacterium, for which the name Microbacterium kribbense sp. nov. is proposed.

\section{Description of Microbacterium kribbense sp. nov.}

Microbacterium kribbense (krib.ben'se. N.L. neut. adj. kribbense arbitrary adjective formed from the acronym of the Korea Research Institute of Bioscience and Biotechnology, KRIBB, where the taxonomic studies on the type strain were performed).

Gram-positive, non-motile, catalase-negative and aerobic. Colonies are pale to lemon yellow in colour. Cells are irregular rods, $0.4-0.6 \times 0.5-0.8 \mu \mathrm{m}$ in size. Growth occurs at $\mathrm{pH} 7-11$ and $20-37^{\circ} \mathrm{C}$; optimal growth occurs at $\mathrm{pH} 7.2-7.4$ and $28{ }^{\circ} \mathrm{C} . \mathrm{NaCl}$ is tolerated at concentrations up to $3 \%$. Arabinose, galactose, glucose, maltose, mannitol, mannose, melibiose, raffinose, rhamnose, sucrose and trehalose are assimilated, but ribose, fructose and xylose are not. Nitrate is reduced to nitrite. Aesculin, starch and Tween 80 are hydrolysed, but cellulose, gelatin and urea are not. Esterase (C4), esterase lipase (C8), leucine arylamidase, acid phosphatase, naphthol-AS-BI-phosphohydrolase, $\alpha$-galactosidase, $\beta$-glucuronidase, $\alpha$-glucosidase, $\beta$ glucosidase and $N$-acetyl- $\beta$-glucosaminidase are detected with the API ZYM enzyme assay; alkaline phosphatase, lipase (C14), valine arylamidase, cystine arylamidase, trypsin, $\alpha$-chymotrypsin, $\beta$-galactosidase, $\alpha$-mannosidase and $\alpha$-fucosidase are negative. The diagnostic diamino acid isomer of the peptidoglycan is L-lysine. The acyl type of the peptidoglycan is $\mathrm{N}$-glycolyl. The predominant menaquinones are MK-11 and MK-12. The main polar lipids are diphosphatidylglycerol and phosphatidylglycerol. The major cellular fatty acids are $\mathrm{C}_{18: 1} \omega 7 c$, anteiso- $\mathrm{C}_{15: 0}$, iso$\mathrm{C}_{16: 0}$, anteiso- $\mathrm{C}_{17: 0}$, iso- $\mathrm{C}_{15: 0}$ and iso- $\mathrm{C}_{17: 0}$. Whole-cell hydrolysate contains ribose, galactose, glucose and xylose. The DNA G + C content of the type strain is $71.0 \mathrm{~mol} \%$.
The type strain, MSL- $04^{\mathrm{T}} \quad\left(=\mathrm{KCTC} 19269^{\mathrm{T}}=\mathrm{DSM}\right.$ $\left.19265^{\mathrm{T}}\right)$, was isolated from a soil sample collected from Bigeum Island, Korea.

\section{Acknowledgements}

This work was supported by the 21C Frontier Microbial Genomics and Application Centre Program, Korean Ministry of Science and Technology (MOST), and the Korea Foundation for International Cooperation of Science and Technology (KICOS) through a grant provided by MOST in the Global Partnership Program (no. M60602000001-06E0200-00100) of the Republic of Korea.

\section{References}

Chen, H.-H., Li, W.-J., Tang, S.-K., Kroppenstedt, R. M., Stackebrandt, E., Xu, L.-H. \& Jiang, C.-L. (2004). Corynebacterium halotolerans sp. nov., isolated from saline soil in the west of China. Int J Syst Evol Microbiol 54, 779-782.

Collins, M. D., Jones, D. \& Kroppenstedt, R. M. (1983). Reclassification of Brevibacterium imperiale (Steinhaus) and "Corynebacterium laevaniformans" (Dias and Bhat) in a redefined genus Microbacterium (Orla-Jensen), as Microbacterium imperiale comb. nov. and Microbacterium laevaniformans nom. rev.; comb. nov. Syst Appl Microbiol 4, 65-78.

Cowan, S. T. \& Steel, K. J. (1965). Manual for the Identification of Medical Bacteria. Cambridge: Cambridge University Press.

Cui, X.-L., Mao, P.-H., Zeng, M., Li, W.-J., Zhang, L.-P., Xu, L.-H. \& Jiang, C.-L. (2001). Streptimonospora salina gen. nov., sp. nov., a new member of the family Nocardiopsaceae. Int J Syst Evol Microbiol 51, 357-363.

De Ley, J., Cattoir, H. \& Reynaerts, A. (1970). The quantitative measurement of DNA hybridization from renaturation rates. Eur $J$ Biochem 12, 133-142.

Deibel, R. H. \& Ewans, J. B. (1960). Modified benzidine test for the detection of cytochrome-containing respiratory systems in microorganisms. J Bacteriol 79, 356-360.

Felsenstein, J. (1981). Evolutionary trees from DNA sequences: a maximum likelihood approach. $J$ Mol Evol 17, 368-376.

Felsenstein, J. (1985). Confidence limits on phylogenies: an approach using the bootstrap. Evolution 39, 783-791.

Felsenstein, J. (1993). PHYLIP (phylogeny inference package), version 3.5. Distributed by the author. Department of Genome Sciences, University of Washington, Seattle, USA.

Fitch, W. M. \& Margoliash, E. (1967). Construction of phylogenetic trees: a method based on mutation distances as estimated from cytochrome $c$ sequences is of general applicability. Science 155, 279284.

Groth, I., Schumann, P., Weiss, N., Martin, K. \& Rainey, F. A. (1996). Agrococcus jenensis gen. nov., sp. nov., a new genus of actinomycetes with diaminobutyric acid in the cell wall. Int J Syst Bacteriol 46, 234-239.

Huß, V. A. R., Festl, H. \& Schleifer, K. H. (1983). Studies on the spectrophotometric determination of DNA hybridization from renaturation rates. Syst Appl Microbiol 4, 184-192.

Imai, K., Takeuchi, M. \& Banno, I. (1984). Reclassification of "Flavobacterium arborescens" (Frankland and Frankland) Bergey et al. in the genus Microbacterium (Orla-Jensen) Collins et al., as Microbacterium arborescens comb. nov., nom. rev. Curr Microbiol 11, 281-284. 
Jahnke, K. D. (1992). BASIC computer program for evaluation of spectroscopic DNA renaturation data from Gilford System 2600 spectrophotometer on a $\mathrm{PC} / \mathrm{XT} / \mathrm{AT}$ type personal computer. J Microbiol Methods 15, 61-73.

Kimura, M. (1980). A simple method for estimating evolutionary rates of base substitutions through comparative studies of nucleotide sequences. J Mol Evol 16, 111-120.

Kimura, M. (1983). The Neutral Theory of Molecular Evolution. Cambridge: Cambridge University Press.

Kluge, A. G. \& Farris, F. S. (1969). Quantitative phyletics and the evolution of anurans. Syst Zool 18, 1-32.

Kumar, S., Tamura, K., Jakobsen, I.-B. \& Nei, M. (2001). MEGA2: molecular evolutionary genetics analysis software. Bioinformatics 17, 1244-1245.

Leifson, E. (1963). Determination of carbohydrate metabolism of marine bacteria. J Bacteriol 85, 1183-1184.

Li, W.-J., Chen, H.-H., Xu, P., Zhang, Y.-Q., Schumann, P., Tang, S.-K., Xu, L.-H. \& Jiang, C.-L. (2004a). Yania halotolerans gen. nov., sp. nov., a novel member of the suborder Micrococcineae from saline soil in China. Int J Syst Evol Microbiol 54, 525-531.

Li, W.-J., Chen, H.-H., Zhang, Y.-Q., Schumann, P., Stackebrandt, E., Xu, L.-H. \& Jiang, C.-L. (2004b). Nesterenkonia halotolerans sp. nov. and Nesterenkonia xinjiangensis sp. nov., actinobacteria from saline soils in the west of China. Int J Syst Evol Microbiol 54, 837-841.

MacKenzie, S. L. (1987). Gas chromatographic analysis of amino acids as the $N$-heptafluorobutyryl isobutyl esters. I Assoc Off Anal Chem 70, 151-160.

Marmur, J. (1961). A procedure for the isolation of deoxyribonucleic acid from microorganisms. J Mol Biol 3, 208-218.

Marmur, J. \& Doty, P. (1962). Determination of base composition of deoxyribonucleic acid from its denaturation temperature. J Mol Biol 5, 109-118.

Minnikin, D. E., Patel, P. V., Alshamaony, L. \& Goodfellow, M. (1977). Polar lipid composition in the classification of Nocardia and related bacteria. Int J Syst Bacteriol 27, 104-117.
Orla-Jensen, S. (1919). The Lactic Acid Bacteria. Copenhagen: Høst \& Sons.

Rivas, R., Trujillo, M. E., Sánchez, M., Mateos, P. F., Martínez-Molina, E. \& Velázquez, E. (2004). Microbacterium ulmi sp. nov., a xylanolytic, phosphate-solubilizing bacterium isolated from sawdust of Ulmus nigra. Int J Syst Evol Microbiol 54, 513-517.

Saitou, N. \& Nei, M. (1987). The neighbor-joining method: a new method for reconstructing phylogenetic trees. Mol Biol Evol 4, 406425.

Schleifer, K. H. (1985). Analysis of the chemical composition and primary structure of murein. Methods Microbiol 18, 123-156.

Schleifer, K. H. \& Kandler, O. (1972). Peptidoglycan types of bacterial cell walls and their taxonomic implications. Bacteriol Rev 36, 407-477.

Shirling, E. B. \& Gottlieb, D. (1966). Methods for characterization of Streptomyces species. Int J Syst Bacteriol 16, 313-340.

Takeuchi, M. \& Hatano, K. (1998). Union of the genera Microbacterium Orla-Jensen and Aureobacterium Collins et al. in a redefined genus Microbacterium. Int J Syst Bacteriol 48, 739-747.

Tang, S.-K., Li, W.-J., Dong, W., Zhang, Y.-G., Xu, L.-H. \& Jiang, C.-L. (2003). Studies of the biological characteristics of some halophilic and halotolerant actinomycetes isolated from saline and alkaline soils. Actinomycetologica 17, 6-10.

Tarrand, J. J. \& Groschel, D. H. M. (1982). Rapid, modified oxidase test for oxidase-variable bacterial isolates. J Clin Microbiol 16, 772774 .

Thompson, J. D., Gibson, T. J., Plewniak, F., Jeanmougin, F. \& Higgins, D. G. (1997). The CLUSTAL_X windows interface: flexible strategies for multiple sequence alignment aided by quality analysis tools. Nucleic Acids Res 25, 4876-4882.

Wayne, L. G., Brenner, D. J., Colwell, R. R., Grimont, P. A. D., Kandler, O., Krichevsky, M. I., Moore, L. H., Moore, W. E. C., Murray, R. G. E. \& other authors (1987). International Committee on Systematic Bacteriology. Report of the ad hoc committee on reconciliation of approaches to bacterial systematics. Int $J$ Syst Bacteriol 37, 463-464. 